
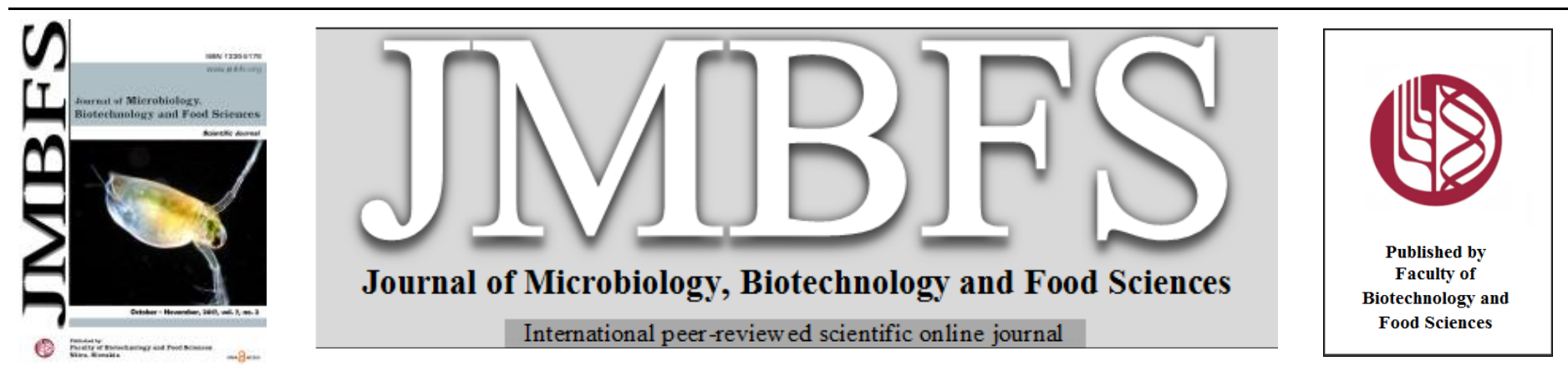

\title{
BIOFILM PRODUCTION BY Staphylococcus sp ON STAINLESS STEEL CHIPS IN CONTACT WITH BRAZILIAN MINAS CHEESE HOMOGENATES AND BHI BROTH UNDER DIFFERENT EXTRINSIC FACTORS
}

\author{
Nathália C.C. Silva ${ }^{1}$, Érika C.R. Bonsaglia ${ }^{2}$, Ary Fernandes Júnior $^{2}$, Rodrigo T. Hernandes $^{2}$; José C.F. Pantoja ${ }^{3}$, Vera L.M. Rall ${ }^{2}$
}

Address(es): Nathália Silva,

${ }^{1}$ Department of Food Science, Faculty of Food Engineering (FEA), University of Campinas (UNICAMP), 13083-862, Campinas, Sao Paulo, Brazil. Tel. (+55 19) 3251 4012, Fax (+55 19) 32510064 .

${ }^{2}$ Department of Microbiology and Immunology, Bioscience Institute, Distrito de Rubião Junior S/N, CEP: 18618-970, Universidade Estadual Paulista (UNESP), Botucatu, SP, Brazil

${ }^{3}$ Department of Hygiene Veterinary and Public Health, Distrito de Rubião Junior S/N, CEP: 18618-970, Universidade Estadual Paulista (UNESP), Botucatu, SP, Brazil.

*Corresponding author: ncirone@unicamp.br

doi: 10.15414/jmbfs.2017.7.2.190-192

\section{ARTICLE INFO}

Received 12.1.2016

Revised 5. 1. 2017

Accepted 20.9. 2017

Published 1. 10. 2017

Short communication

open $\mathcal{O}$ access

\section{ABSTRACT}

The aim of this study was to evaluate biofilm production by Staphylococcus sp on stainless steel using brain heart infusion (BHI) broth and Minas Frescal cheese broth, at different levels of contamination and under different temperatures, atmospheres. The cheeses were classified according to their microbiota. It was evaluated biofilm formation on stainless steel chips at 8,15 and $35^{\circ} \mathrm{C}$ after 48,72 and 96 $\mathrm{h}$ under different conditions. Both Staphylococcus isolates formed biofilm on stainless steel chip in BHI broth and cheese broth, under all temperatures and atmospheres studied. In conclusion, BHI broth and Brazilian Minas cheese homogenate performed equally well for biofilm formation tests using Staphylococcus strains, and S. aureus can produce biofilm on stainless steel at $8^{\circ} \mathrm{C}$, which may be a concern for the dairy industry. Finally, it is important to consider that $S$. aureus can be a good competitor, depending on the nature of the microbiota.

Keywords: Staphylococcus aureus; atmosphere; biofilm; temperature; microbiota

\section{INTRODUCTION}

Dairy products have been frequently associated with foodborne illness (Veras $\boldsymbol{e t}$ al., 2008; Schmid et al., 2009). In Brazil, Minas cheese is the most popular cheese, produced by the direct acidification of milk or by adding lactic cultures (Carvalho et al,. 2007). This cheese can also be handmade on small farms with raw milk, without proper hygiene control, resulting in a product with high levels of bacterial contamination, including Staphylococcus sp and coliforms (Carvalho et al., 2007; Rall et al., 2010).

Staphylococcus species are commonly found in cheese, with S. aureus being the major pathogenic species. Some strains of this genus are able to produce enterotoxin (Rall et al., 2010) and form biofilm on abiotic surfaces (Schlegelová et al., 2008; Gutiérrez et al., 2012). Flaws in cleaning processes allow the contaminating bacteria to attach to equipment surfaces and become a potential source of contamination in the food industry (Schlegelová et al., 2008, Gutiérrez et al., 2012).

The production of polysaccharide intercellular adhesin (PIA) is mediated by the ica (intercellular adhesion) operon (Cramton et al., 1999), which consists of the $i c a \mathrm{~A}, i c a \mathrm{~B}, i c a \mathrm{C}$ and $i c a \mathrm{D}$ genes. ica $\mathrm{A}$ and $i c a \mathrm{D}$ are of great importance in biofilm production (Vasudevan et al., 2003). Other important genes that also produce proteins that regulate biofilm formation are bap (biofilm-associated protein) and agr (accessory gene regulator) (Melchior et al., 2009).

The aim of this study was to evaluate biofilm production on stainless steel by Staphylococcus sp, using Minas Frescal cheese broth and brain heart infusion (BHI) broth as nutrient media, at different levels of contamination and under different temperatures and atmospheres.

\section{MATERIAL AND METHODS}

\section{Microbial quality of cheese samples}

We acquired different brands of cheese at retail in the city of Botucatu, SP Brazil and the temperatures of all purchases (12 - 2 samples per purchase) were measured with a digital infrared thermometer with laser sight (Incoterm, Porto Alegre, Brazil). A total of 24 samples were analyzed, and the samples were classified as having low-level contamination when they had up to $10^{3}$ colony forming units (CFU)/g of mesophilic and psychrotrophic bacteria (PCA medium), in the absence of thermotolerant coliforms (EC broth) and Staphylococcus sp. (Baird Parker agar). They were classified as having a high-level of microbiota when we detected more than $10^{3} \mathrm{CFU} / \mathrm{g}$ of mesophilic and psychrotrophic bacteria and more than $10^{3}$ most probable number (MPN) of thermotolerant coliforms/g, in the absence of Staphylococcus sp. All tests were performed with Oxoid culture media (Oxoid, Basingstoke, UK).

Determination of the MPN of thermotolerant coliforms was carried out according to the American Public Health Association (Kornacki and Johnson, 2001) in a three-tube series of each dilution. The MPN of thermotolerant coliforms was calculated based on gas production in tubes of E. coli broth at $45^{\circ} \mathrm{C}$ after $24 \mathrm{~h}$.

Staphylococcus sp counts were determined according to Lancette and Bennett (2001), where serial dilutions of cheese homogenate were plated on Baird Parker agar with $5 \%$ egg yolk tellurite emulsion and incubated at $35^{\circ} \mathrm{C}$ for $48 \mathrm{~h}$ Characteristic colonies were tested for catalase, thermonuclease, and coagulase, and with the Staphytect Plus Dry Spot Kit (OXOID).

The pour plate method was used for mesophilic bacterial enumeration. CFUs were counted after incubation at $35^{\circ} \mathrm{C} / 24 \mathrm{~h}$. Psychrotrophic bacteria were determinated using the spread method, $0.1 \mathrm{~mL}$ of each serial dilution was plated on the surface of the plate count agar. The plates were incubated at $4^{\circ} \mathrm{C}$ for 7 days (Morton 2001).

\section{Production and quantification of biofilm (Stepanovic et al. 2000).}

We used stainless steel (AISI 304) chips to detect biofilm production and the temperatures used were 8 (refrigeration temperature by law), 15 (average temperature found in retail), and $35^{\circ} \mathrm{C}$. Sterile stainless chips $(1 \mathrm{~cm}$ diameter were placed in 24-well plates. The experiment was performed in triplicate.

The positive and negative controls were Staphylococcus epidermidis (ATCC 35984 and ATCC 12.228, respectively), and a S. aureus strain, isolated from milk and positive for $i c a \mathrm{~A}, i c a \mathrm{D}$, and $b a p$ genes (data not shown) were used for the tests (Vasudevan et al., 2003, Cucarella et al., 2001).

The strains were incubated in $\mathrm{BHI}$ broth at $35^{\circ} \mathrm{C} / 24 \mathrm{~h}$ and the culture was diluted to $10^{8} \mathrm{CFU} / \mathrm{mL}$. The Densichek (Biomerieux, l'Etoile, France) was used to measure turbidity. This dilution was employed to inoculate a cheese homogenate, which was produced by homogenization of $5 \mathrm{~g}$ of cheese in $45 \mathrm{~mL}$ of saline, with 
high and low contamination. Aliquots of $300 \mu \mathrm{L}$ were distributed in triplicate into the wells of the plate and incubated at 8,15 , and $35^{\circ} \mathrm{C}$ for $96 \mathrm{~h}$. The same was done using bacterial cultures grown in BHI broth. The plates were incubated in aerobiosis and anaerobiosis, using Anaerogen (Oxoid).

We transferred the chips to a new plate to prevent the quantification of biofilm that might have been produced on the plastic surface around the chips, that were washed three times with PBS (pH 7.4) to remove non-adherent bacterial cells, stained with $1 \%$ crystal violet for $15 \mathrm{~min}$, and then washed three times. The biofilm was resuspended in $300 \mu \mathrm{L}$ of glacial acetic acid for $15 \mathrm{~min}$ to ensure the homogeneity of the stained material. Next, $200 \mu \mathrm{L}$ were transferred to a 96-well microplate, which was read in an ELISA reader (Babsystems, EX multiskan) at $570 \mathrm{~nm}$. Non-inoculated BHI and cheese broth were used as blanks to correct the absorbance value. The strains were classified on the basis of biofilm production as non-producers, or weak, moderate, or strong producers, according to Stepanovic et al. (2000)

\section{Statistical Analysis}

Initially, the distribution of OD was examined using histograms and norma probability plots. No departures from a normal distribution were found. Thus, a repeated measures model (PROC MIXED, SAS Institute, 2011) was used to compare the mean OD (response variable) between time points (48, 72 or $96 \mathrm{~h}$ ), sample types (BHI and low contaminant or high contaminant cheese broth), temperatures $\left(8,15\right.$ or $35^{\circ} \mathrm{C}$ ), environment (aerobic or anaerobic) and strains (wild-type or ATCC). Interaction terms between time point and each explanatory variable were included in the model to test the hypothesis that the difference between sample types, temperatures, environments, and strains depended on the time point analyzed. An autoregressive covariance structure was used to mode the correlation between the repeated measurements within the same sample Tukey's test was used to adjust the P-values resulting from multiple comparisons. Statistical significance was set at $\mathrm{P}<0.05$

\section{RESULTS AND DISCUSSION}

Most commercial establishments evaluated in the current study did not have adequate refrigeration, with storage temperatures ranging from 8.4 to $18.6^{\circ} \mathrm{C}$, with a median of $14.6^{\circ} \mathrm{C}$, which approximated temperature $\left(15^{\circ} \mathrm{C}\right)$ was one of the temperatures used in this study. In Brazil, other authors also found the use of temperatures in supermarkets above that recommended for cold storage, with inadequate temperatures in $70 \%$ (Chesca et al., 2001) and 66\% (Lima and Fernandes, 2011) of the establishments studied. Different results were obtained in London, England by Hobbs and Roberts (1998), where only $19.7 \%$ of 559 refrigerators did not use a proper temperature. Such observation is probably due to better awareness and greater vigilance on the part of the responsible authorities.

At $96 \mathrm{~h}$, both strains ( $S$. epidermidis and $S$. aureus) showed weak biofilm production, according to the definitions of Stepanovic et al. (2000) at al temperatures tested $\left(8,15\right.$ and $\left.35^{\circ} \mathrm{C}\right)$ and experimental conditions (cheese homogenate with high or low contamination and BHI broth kept under aerobic and anaerobic atmosphere), with no significant difference between the variables, showing that the BHI broth provided similar conditions as cheese broth for biofilm production, at least for the isolates studied, which were classified as weak producers here. Surprisingly, the cheese's microbiota showed no influence on biofilm production, since $S$. aureus is not considered a good competitor (Rode $\boldsymbol{e}$ al., 2007). However, it is important to consider that selective pressure may vary according to the microbiota present in the cheese.

The study showed that biofilm formation was higher at $15^{\circ} \mathrm{C}$ and $35^{\circ} \mathrm{C}$, in comparison to $8{ }^{\circ} \mathrm{C}$. When $15^{\circ} \mathrm{C}$ and $35^{\circ} \mathrm{C}$ were compared, biofilm formation was similar $(\mathrm{P}>0.05)$. These results were expected and confirmed that storage temperature is very important to prevent biofilm formation.

This observation may be a warning, since, biofilm formation occurred at $8^{\circ} \mathrm{C}$ and higher. Rode $\boldsymbol{e t}$ al. (2007) conducted a study on biofilm formation by $S$. aureus in tryptic soy broth (TSB) at temperatures ranging from 20 to $48^{\circ} \mathrm{C}$ and observed higher biofilm formation at 25 and $30^{\circ} \mathrm{C}$. These temperatures is almost the optimal temperature of $35^{\circ} \mathrm{C}$ studied in this study and it is common these temperatures, mainly in Brazil where the room temperature could be $30^{\circ} \mathrm{C}$.

No significant differences were observed between the temperatures and atmospheres employed in the present study. This suggests that temperature does not influence biofilm production. So far, temperatures that really inhibit the biofilm formation are still unknown, where this question will be important in future studies

Reports using cheese as the nutrient medium for biofilm production were not found, and few other studies have investigated the influence of temperature and atmosphere on biofilm production (Jaglic et al., 2011). The most commonly used temperature for investigating biofilm formation is $37^{\circ} \mathrm{C}$, since it is the optimal temperature for growth and biofilm production by these bacteria (Beenken $\boldsymbol{e t}$ al. 2003). However, it is important to consider that $37^{\circ} \mathrm{C}$ could not correspond to storage and chilled temperatures and this study showed that biofilm could be formed in low temperature.
Some authors, such as Michu et al. (2011), used milk to evaluate biofilm formation by $S$. epidermidis on stainless steel chips at different concentrations of $\mathrm{NaCl}$ and glucose by analyzing the expression of the icaA gene using qPCR at $30^{\circ} \mathrm{C}$ at 8 and $20 \mathrm{~h}$. This gene was expressed in all milk samples tested, and expression was substantially higher at $20 \mathrm{~h}$. However, it should be emphasized that the presence of mRNA does not imply production of the corresponding protein, which is dependent on mRNA stability and translation rate (Lodish et al., 2005).

Jaglic et al., (2011) studied the adherence of $S$. epidermidis to stainless steel, employing milk as a culture medium at different temperatures: 6,22 , and $28^{\circ} \mathrm{C}$. In a 6-h assay, they observed that bacterial adherence to stainless steel, when incubated with milk, was higher than that observed in assays performed in TSB. After $6 \mathrm{~h}$ at $6^{\circ} \mathrm{C}$, adherence to stainless steel was sufficient for biofilm formation, where the temperature investigated in that assay $\left(6^{\circ} \mathrm{C}\right)$ was very close to the temperature employed in this study $\left(8^{\circ} \mathrm{C}\right)$.

Biofilm formation in stainless steel is a concern in the milk industry, even at low temperatures, at which products are kept $\left(3\right.$ to $\left.6^{\circ} \mathrm{C}\right)$. This situation also occurs in other kinds of dairy plants, such as those that produce some cheeses and yogurts, where temperatures can reach $30^{\circ} \mathrm{C}$. On the surfaces of equipment, where there is cooling pasteurization, biofilm can grow and contaminate other products (Knight et al. 2004). Schlegelová et al. (2008) and Melchior et al. (2009) isolated Staphylococcus sp. with genes related to biofilm production, including the ica cluster and bap, from dairy plants.

\section{CONCLUSION}

In conclusion, under the conditions tested here, Staphylococcus sp. can form biofilms on stainless steel chips with cheese as a nutrient at $8^{\circ} \mathrm{C}$, which represents an important problem for the dairy industry. The use of BHI broth allowed us to obtain similar results as those observed with cheese homogenate, indicating that it could be successfully used in cheese researches. Finally, the conception that $S$. aureus is always a poor competitor against competitive microbiota should be reviewed; maybe it depends on the nature of the microbiota.

\section{REFERENCES}

Beenken, K.E, Blevins, J.S., Smeltzer, M.S. (2003). Mutation of sarA in Staphylococcus aureus limits biofilm formation. Infect. Immun. 71(7):42064211. http://dx.doi.org/10.1128/iai.71.7.4206-4211.2003

Carvalho, J.D.G., Viotto, W.H., Kuaye, A.Y. (2007). The quality of Minas frescal cheese produced by different technological processes. Food Control 18: 262 267. http://dx.doi.org/10.1016/j.foodcont.2005.10.005

Chesca, A.C., Peixoto, C.P., Costa, D.G., Nascimento, H.N., Pinto, I.R.A. Guimarães, J.L.P., Tarquinio, L.B., Okura, M.H. (2001). Levantamento das temperaturas de armazenamento de carnes, em açougues e supermercados de Uberaba, MG. Hig. Aliment. 15(84):51-55.

Cramton, S.E., Gerke, C., Schnell, N.F., Nichols, W.W., Gotz, F. (1999). The intercellular adhesion (ica) locus is presente in Staphylococcus aureus and is required for biofilm formation. Infect. Immun. 67:5427-5433 http://dx.doi.org/10.1128/aem.69.9.5648-5655.2003

Cucarella, C., Colano, C., Valle, J., Amorena, B., Lasa, I., Penades, P. (2001). Bap, a Staphylococcus aureus surface protein involved in biofilm formation. $J$. Bacteriol. 183:2888-2896. http://dx.doi.org/10.1128/jb.183.9.2888-2896.2001

Gutiérrez, D., Delgado, S., Vázquez-Sánchez, D., Martínez, B., Cabo, M.L. Rodríguez, A., Herrera, J.J., García, P. (2012). Incidence of Staphylococcus aureus and analysis of associated bacterial communities on food industry $\begin{array}{llll}\text { surfaces. } & \text { Appl. } & \text { Environ. } & \text { Microbiol. }\end{array}$ http://dx.doi.org/10.1128/aem.02045-12

Hobbs, B.C., D. Roberts (1998) Toxiinfecções e controle higiênico-sanitário de alimentos. Varela, São Paulo.

Jaglic, Z., Cervinkova, D., Michu, E., Holasova, M., Roubal, P., Vlkova, H., Babak, V., Schlegelova, J. (2011). Effect of milk temperature and flow on the adherence of Staphylococcus epidermidis to stainless steel in amounts capable of biofilm formation. Dairy Sci. Tech. 91:361-372. http://dx.doi.org/10.1007/s13594-011-0017-6

Knight, G.C., Nicol, R.S., McMeekin, T.A. (2004). Temperature step changes: a novel approach to control biofilms of Streptococcus thermophilus in a pilot plantscale cheese-milk pasteurization plant. Int. J. Food Microbiol. 93:305318. http://dx.doi.org/10.1016/j.ijfoodmicro.2003.11.013

Kornacki, J.L., Johnson, J.L. (2001). Enterobacteriaceae, coliforms, and Escherichia coli as quality and safety indicators, p. 69-80 In: DOWNES FP; ITO $\mathrm{K}$ (Eds). Compendium of Methods for the Microbiological Examination of Foods. Washington:Apha.

Lancette, G.A., Bennett, R.W. (2001). Staphylococcus aureus and staphylococcal enterotoxins, p. 387-403 In: Downes, F. P., K. Ito. (Eds.) Compendium of Methods for the Microbiological Examination of Foods. Apha, Washington.

Lima, C., Fernandes, M. (2011). Monitoring the temperatures of refrigeration equipment in supermarkets in the city of Maceió, AL. Hig. Aliment. 25:35-39.

Lodish, H., Berh, A., Matsudaira, P., Kaiser, C.A., Krieger, M., Scott, M.P. (2005). Biologia Celular e Molecular. ArtMed, Porto Alegre. 
Melchior, M.B., van Osch, M.H.J., Graat, R.M., van Duijkeren, E., Mevius, D.J., Nielen, M., Gaastra, W., Fink-Gremmels, J. (2009). Biofilm formation and genotyping of Staphylococcus aureus bovine mastitis isolates: Evidence for lack of penicillin-resistance in agr-type II strains. Vet. Microbiol. 137:83-89. http://dx.doi.org/10.1016/j.vetmic.2008.12.004

Michu, E., Cervinkova, D., Babak, V., Kyrova, K., Jaglic, Z. (2011). Biofilm formation on stainless steel by Staphylococcus epidermidis in milk and influence of glucose and sodium chloride on the development of ica-mediated biofilms. Int Dairy J. 21:179 - 184. http://dx.doi.org/10.1016/j.idairyj.2010.10.004

Morton, R.D. (2001) Aerobic Plate Count, p. 63-67. In: DOWNES F. P; ITO, K. (Eds). Compendium of Methods for the Microbiological Examination of Foods.Washington:Apha.

Rall, V.L.M., Sforcin, J.M., Deus, M.F.R., Sousa, D.C., Camargo, C.H., Godinho, N.C., Galindo, L.A., Soares, T.C.S., Araújo Jr, J.P. (2010). Polymerase chain reaction detection of enterotoxins genes in coagulase-negative Staphylococci isolated from Brazilian Minas cheese. Food. Pathog. Dis. 7(9):1121-1123. http://dx.doi.org/10.1089/fpd.2009.0478

Rode, T.M., Langsrud, S., Holck, A., Møretrø, T. (2007). Different patterns of biofilm formation in Staphylococcus aureus under food-related stress conditions. $\begin{array}{llll}\text { Int. } & J & \text { Food } & \text { Microbiol. }\end{array}$ http://dx.doi.org/10.1016/j.ijfoodmicro.2007.02.017

Schlegelová, J., Babák, M., Holasová, V., Dendis, M. (2008). The biofilmpositive Staphylococcus epidermidis isolates in raw materials, foodstuffs and on contact surfaces in processing plants. Folia Microbiol. 53(6):500-504 http://dx.doi.org/10.1007/s12223-008-0078-y

Schmid, D., Fretz, R., Winter, P., Mann, M., Höger, G., Stöger, A., Ruppitsch W., Ladstätter, J., Mayer, N., Martin, A., Allerberger, F. (2009). Outbreak of staphylococcal food intoxication after consumption of pasteurized milk products, June 2007, Austria. Wien. Klin. Wochenschr. 121:125131. http://dx.doi.org/10.1007/s00508-008-1132-0

Stepanovic, S., Vukovic, D., Dakic, I., Savic, B., Svabic-Vlahovic, M. (2000). A modified microtiter-plate test for quantification of staphylococcal biofilm formation. J. Microbiol. Meth. 40:175-179. http://dx.doi.org/10.1016/s01677012(00)00122-6

Vasudevan, P., Nair, M.K.M., Annamalai, T., Venkitanarayanan, K. (2003) Phenotypic and genotypic characterization of bovine mastitis isolates of Staphylococcus aureus for biofilm formation. Vet. Microbiol. 92, 179185. http://dx.doi.org/10.1016/s0378-1135(02)00360-7

Veras, J.F., do Carmo, L.S., Tong, L.C., Shupp, J.W., Cummings, C., Dos Santos, D.A., Cerqueira, M.M., Cantini, A., Nicoli, J.R., Jett, M. (2008). A study of the enterotoxigenicity of coagulase-negative and coagulase-positive staphylococca isolates from food poisoning outbreaks in Minas Gerais, Brazil. Int. J. Infect. Dis. 12:410-415. http://dx.doi.org/10.1016/j.ijid.2007.09.018 